\title{
SPESIESISME - FENOMENETS GRUNNLAG OG KONSEKVENSER ${ }^{*}$
}

AV FORSKER, DR. POLIT. RAGNHILD SOLLUND

\begin{abstract}
Speciesism is defined as a prejudice that gives priority to human beings over non-human animals. In spite of animal protection legislation, the animals that are used in factory and fur farming, as well as research, seem to be without legal protection. This article discusses the basis for speciesism in order to establish whether mechanisms like social and physical distance, industrialization, and alienation facilitate the abuse of animals. Human beings' ways of treating "the others" are thereby central to the article."
\end{abstract}

\section{Innledning}

Fenomenet "spesiesisme" defineres av filosofen Peter Singer (1975), som en fordom som favoriserer interessene til dem av samme art som en selv. Jeg vil diskutere grunnlaget for det. Geertrui Cazaux (1998) og Josephine Donovan (1990) argumenterer for at alle typer undertrykkelse, knyttet til rase, kjønn eller art henger sammen. Piers Beirne sier det er likheter i handling, rettferdiggjørelse og språkbruk, selv om undertrykkelsen har forskjellige ofre. Menneskers måte å behandle "De andre" på vil derfor være sentralt $\mathrm{i}$ artikkelen. Mens sexisme og rasisme ikke er allment akseptert i moderne, vestlige samfunn skal vi se om behandlingen dyr utsettes for, kan knyttes til en kulturell legitimitet. Kanskje kan sosial avstand bidra til å forklare forskjellen i måten vi behandler dyr på, som er objekter for materiell bruk innenfor matproduksjon, pelsproduksjon og forskning, i kontrast til våre kjæledyr (Christie 1989).

Innen filosofien har to retninger satt viktige spor i debatten knyttet til dyrs rettigheter. Den første er Singers utilitaristiske argumentasjon i boken Animal Liberation (1975). Den er knyttet til prinsipper om lik vekt på arters interesser. Dette innebærer $i k k e$ lik behandling, men at alle som kan føle smerte har en like stor interesse i å unngå det. Karakteristikken av et sansende vesen er dermed grensen for hvordan vi skal behandle dyr. Singer tar utgangspunkt i

\footnotetext{
- Takk til Hedda Giertsen for utallige kommentarer til artikkelen som var min selvvalgte prøveforelesning til dr.polit.graden (avlagt 11.og 12.9.2003). Takk også til Liv Os Stølan for kommentarar da prøveforelesningen var i paperform etter å ha blitt presentert ved The European Group for the Study of Deviance and Social Controls konferanse i Krakow sept. 2002.

"* Title in English: Speciesism - the Basis and Consequences of Discrimination Based on Species. Original in Norwegian.
} 
Jeremy Benthams berømte sitat:" Spørsmålet er ikke om dyr kan resonnere, heller ikke om de kan snakke, men om de kan lide".

Den andre retningen er Tom Regans (1999) naturrettsperspektiv, hvor han hevder at dyr har naturlige, moralske rettigheter som innebærer at de ikke skal plages og drepes. Alle individer som er "subjekter for et liv", har iboende verdi, uavhengig av deres nytte for andre. De har gode og dårlige opplevelser avhengig av hva som hender med dem. Moralske rettigheter kan ikke være avhengige av evnen til å tenke på et abstrakt nivå. Det ville ha alvorlige implikasjoner som ikke bare berører dyrs rettigheter, men også menneskerettigheter. For det å akseptere eksperimenter med voksne dyr, som for eksempel hunder og sjimpanser, vil logisk medføre aksept av eksperimenter med babyer og psykisk utviklingshemmede, fordi de har mindre intellektuell kapasitet enn voksne dyr (Regan 1999).

Singers og Regans filosofiske tilnærminger har bidratt til en økende motstand mot dyremishandling, og til at dyrs rettigheter er inkludert som egen disiplin innenfor filosofi på mange universiteter i USA. Beirne $(1995,1999)$ og Cazaux $(1998,1999)$ kritiserer kriminologiens manglende interesse for dyremishandling for å være gjennomgående spesiesistisk og argumenterer for at dyrs lidelse og de etiske spørsmål mishandling reiser må være gjenstand for forskning, fordi dyr skal beskyttes gjennom lovverket, fordi mishandling innebærer smerte og lidelse, brudd på rettigheter, og er en alvorlig form for undertrykkelse. Beirne og Cazaux (1999) hevder at lovverket ikke fungerer som vern for dyr. I Norge er dyrs rettigheter ut fra et etisk perspektiv blitt forfektet i bl.a. Føllesdal (red. 2000).

På den annen side etterspørres det stadig billigere kjøtt, og pels er mote. Det er tilsynelatende et misforhold mellom folks holdninger til dyrevelferd, og forbrukspraksis. Bakgrunnen for dette paradokset vil jeg komme nærmere inn på etter hvert.

\section{Mishandling}

Men når er behandlingen av dyr mishandling? Beirne (1999: 121) definerer dyremishandling som enhver handling som bidrar til å påføre et dyr smerte, lidelse eller død, eller på annen måte truer dets velferd. Det være seg fysisk, psykisk, intendert eller utilsiktet.

\subsection{Industrielt husdyrhold}

Hvert år blir ca. 1,3 millioner griser slaktet i Norge. Ett tusen dør utilsiktet på grunn av stress Grisene utvikler, som en konsekvens av trangboddhet og mangel på stimuli, stereotyp atferd; fra å tygge uten å ha noe å tygge på, og bite hverandres haler ned til roten - til apati. Fordi purka ikke har plass til å snu seg blir gris- 
unger klemt $\mathrm{i}$ hjel. Betonggulvet gir sår og benbrudd. Slaktegrisene legger på seg en kilo om dagen, men er konstant sultne takket være det konsentrerte foret. Avl har frembrakt griser med ryggproblemer og griser som fødes med lamme bakparter. Også melkekyr tilbringer livet i trange båser, som hindrer dem i å bevege seg og jurbetennelse er vanlig (Frøslie 2000)

Nittifem prosent av Norges 3,6 millioner høner er burhøns. Tre høner deler hvert bur, og har plass tilsvarende et a-4 ark: "De kan spise og drikke, og verpe selvfølgelig, men det er også alt de kan" sier Åge Christoffersen (2000) i Rådet for dyreetikk. Over 31 millioner fjærfe ble slaktet i Norge i 2002 (Dyrehelsetilsynet 2003). 66871 døde under oppstalling og transport til slakteriet. Bena til broilerne brekker fordi de blir så tunge. De lever sitt seks uker lange liv i et mørkt rom som holder dem passive og dermed får dem til å vokse hurtigere. Hovedproblemet for fjærkre er for lite plass og mangel på stimuli, noe som blant annet medfører hakking.

\subsection{Pelsdyroppdrett:}

Norge står for $19 \%$ av verdens reveskinnsproduksjon og $1 \%$ av minkpelsproduksjonen. Mink holdes parvis i nettingbur som måler 30x40x90 cm. De lever fire, fem måneder før de avlives med gass, eller ved å få brukket nakken. Også revene holdes to og tre sammen i trange bur før de avlives 7 måneder gamle. Maten i oppdrett er utviklet med tanke på å gi god pelskvalitet, og er ikke i henhold til dyrenes behov. Sykdommer er derfor vanlige. Fordi dyrene fortsatt er ville og holdes i trange bur fattige på stimuli, utvikler de stereotyp atferd, apati og nervøsitet.

Føllesdal (2000), Christoffersen (2000) og Rådet for dyreetikk mener pelsdyrnæringen er den som er vanskeligst å forsvare etisk, på grunn av dens manglende nytteverdi og den omfattende lidelsen den medfører for de ville dyrene i fangenskap.

\subsection{Dyr i forskning}

Et område hvor det forbrukes mange dyr er innenfor forskningen. I Norge ble 500000 dyr avlivet i år 2000. Majoriteten av disse var fisk, men også 43475 hunder, katter, kyr, kaniner, mus, rotter, marsvin, sel og andre arter ble drept i forsøk i Norge. Mange dyr er ikke inkludert i statistikkene, som dyr som avlives før eksperimentene, produksjonsdyr, ville dyr, dyr brukt som kontrollgrupper og dyr som blir avlivet fordi forskeren har bestilt for mange dyr (Dyrevernrapport 1 2002, Dyrevernalliansen). Et estimat av Regan fra 1986 tilsier at 500 millioner dyr drepes i eksperimenter hvert år og at dette utgjør 5\% av alle dyr som årlig drepes av mennesker, rundt ti milliarder. Fisk er ikke inkludert. Men ikke alle 
land fører nøyaktige statistikker, og rotter og mus regnes ikke som dyr i statistikkføringen i USA (Gendin 1986, Regan 2001).

Dyreforsøkene kan grovt deles inn i tre kategorier: Grunnforskning og medisinsk forskning, psykologisk forskning og toksikologiske tester (Gendin 1986).

Thalomidetragedien er et eksempel på medisinske forsøk på dyr, som ikke er egnet til å gi kunnskap om hvordan medisiner virker på mennesker. Thalomide ble utviklet for å forhindre svangerskapskvalme. Tallrike eksperimenter utført på forskjellige dyrearter konkluderte med at Thalomide var ufarlig. Likevel førte Thalomide i bruk på mennesker til at tusenvis av babyer ble født med alvorlige deformiteter (Gendin 1986).

Et annet medisinsk område hvor det forbrukes mange dyr er innenfor kreftforskningen. Likevel skyldes mesteparten av den kunnskapen vi i dag har om hva som fremkaller kreft ikke dyreforsøk, men epidemologiske undersøkelser (Gendin 1986). De fleste incentiver for å teste ut kjemikalier på dyr kommer etter at de først er funnet å være kreftfremkallende hos mennesker, som når man lar 240 beagler inhalere 4000 sigaretter over to år, for så å konstatere at de får lungekreft. Men medisinske dyreforsøk kan ha negative konsekvenser for mennesker. Fordi dyr og mennesker har forskjellig fysiologi og forsøk på dyr dermed ikke kan fortelle hvordan en medisin virker på mennesker, dør det tusenvis av mennesker hver år som følge av utilsiktede og uventede bivirkninger (Singer 1992, Regan 2001, Gendin 1986, Luke 1992).

Singer (1992) gir mange eksempler på at psykologiske forsøk kan synes meningsløse, som å frata apeunger moren og tilby dem en dukke i substitutt, for siden å kunne fastslå at dyret har fått sine sosiale evner svekket. Unødvendig replisering av forsøk er dessuten et stort problem.

Dyr brukes i toksikologiske tester for å undersøke om for eksempel kosmetikkprodukter er giftige for mennesker. Likevel vil de færreste mennesker sprute øynene fulle av hårlakk og sjampo slik kaniner utsettes for (Singer 1992).

\section{Forskjell som forklaring på spesiesisme}

Nærhet, likhet og gjenkjennelse mellom mennesker kan forsterke sympati, mens forskjell kan brukes for å bygge opp en sosial avstand. En undersøkelse om intervenering $\mathrm{i}$ offentlig barnemishandling viste for eksempel at afroamerikanske barn hadde mindre sannsynlighet for å bli hjulpet av det hovedsakelig hvite utvalget (Cohen 2001: 74).

Slik synes menneskers ufølsomhet for andre å øke ved forskjeller i utseende. Forskjellene legitimerer en forskjell i verdi. Man kan skape en følelsesmessig avstand ved å betrakte andre som laverestående. For å kunne mishandle og utnytte andre, for eksempel i krigssituasjoner, kan det derfor være nødvendig å definere ofrene som "De andre", basert på fysiske, kulturelle 
eller andre trekk (Børresen 1996). Stephen J. Gould (1981) sier at appeller til universets natur gjennom historien har blitt brukt til å opphøye eksisterende, sosialt bestemte, hierarkier til å være riktige, uunngåelige og "naturlige". En betydningsfull vitenskapelig gren for å bevise menneskegruppers og kvinners underlegenhet var kraniologien. Det ble "bevist" at den hvite, germanske rase stod øverst, indianere og mongoler under dem, og aller nederst, de svarte - og kvinnene: "(...) den lille kvinnehjernen skyldes delvis hennes fysiske underlegenhet, og delvis hennes intellektuelle underlegenhet" (Broca i Gould 1981: 104).

En konsekvens av å se andre som svært forskjellige, det være seg basert på fysiske kjennetegn som hudfarge, hjernestørrelse eller kjønn, er at det medfører en kulturell legitimering for utnyttelse.

Singer trekker en parallell mellom eksperimenter utført på mennesker og på dyr, som bygger opp for å se forskningsobjektene som forskjellige og mindreverdige, og dermed for rasisme og spesiesisme. Jødiske, polske og russiske krigsfanger ble frosset ned, varmet opp og stengt inne i dekompresjonskamre av nazistene. Resultatene ble beskrevet $\mathrm{i}$ det samme tørre språket som beskriver resultatene fra tilsvarende eksperimenter som ble utført på griser og hunder $\mathrm{i}$ England etter krigen (Singer 1992: 110).

Dette leder hen til én måte å benekte ansvaret for ofrene. De er dehumanisert. Dehumaniserte ofre anses ikke å ha krav på moralske forpliktelser (Cohen 2001, Christie 1989). Dyr er bokstavelig talt dehumanisert. Ncerhet er nødvendig for å gjenkjenne dyrs og menneskers felles trekk. Dyr har få av det Tinbergen har kalt sosiale utløsere, som vekkes når man for eksempel ser et sovende menneske (Børresen 1996). Høner har ikke barns høye panner og kaniners ansikter kan synes uttrykksløse. Det er vanskeligere å "lese" et dyrs smerte. Men for å kunne bruke dyrene for forskjellige formål, som i forskning, har det vært nødvendig å se dem som enda mer forskjellige fra oss enn de er.

Dette synet har sitt utgangspunkt i et mekanistisk verdensbilde, forfektet av René Descartes. Det var på opplysningstiden den vitenskapelige bruk av dyr i forskning ble utviklet. Dyrene ble sett som maskiner, og siden de ikke hadde sjel kunne de heller ikke ha bevissthet eller følelser. Vitenskapsmennene kunne nå operere i levende dyr. Når de skrek, var det kun "sand i maskineriet". Descartes legitimerte og legitimerer fortsatt forsøk med dyr (Regan 1999, Børresen 1996, Luke 1992, Donovan 1990).

I vår tid har behaviorister som Thorndike, Pavlov og Skinner fulgt Descartes (Børresen 1996). Behavioristene har benektet at dyr, selv babyer, kunne føle smerte fordi de ikke hadde språk, og følgelig heller ikke bevissthet. For bare 20 år siden ble spebarn derfor operert uten bedøvelse (Dyrehelsetilsynet 2003). Noe 
av det viktigste for behavioristene er å unngå å antropomorfisere dyr, det vil si å tilegne dem "menneskelige" egenskaper. Alice Heim, tidligere leder for psykologiavdelingen i The British Association for the Advancement of Science, og med 40 års erfaring fra eksperimentell psykologi, sier:

"Arbeider om dyrs 'atferd' uttrykkes alltid i vitenskapelige, hygienisk klingende terminologier. (...) Metoder for 'utslukning' innebarer således i praksis tortur med tørst, sult eller elektriske støt. 'Delvis forsterkning' betyr at man frustrerer et dyr ved å bare av til tilfredsstille de forventninger forsøkslederen har skapt med tidligere trening. (...) Ord som 'smertefull' eller 'skremmende' er mindre o.k. ettersom de er antropomorfe. D.v.s. de antyder at dyr har folelser og at disse følelser kan minne om menneskelige følelser. Det er ikke tillatt. Det er nemlig ikkebehavioristisk og uvitenskapelig. (...) Kardinalsynden for en eksperimentell psykolog som arbeider med 'dyrs atferd' er antropomorfisme. Likevel skulle formodentlig også han synes at hans arbeid $i$ det store og hele manglet berettigelse hvis han ikke trodde på analogien mellom mennesket og det laverestående dyret" (Singer 1992: 78).

Språket brukes dermed for å dekke over realiteten i forsøkene som finner sted. Gjennom språket bygger vi opp avstand for å rede grunnen for mishandling. Andre eksempler er at man reduserer et dyrs verdi ved å kalle dem "det" fremfor "han" eller "hun", og dermed tilslører at de er individer og ikke gjenstander (Adams og Donovan 1995). Forskerne dreper ikke laboratorie-dyrene sine. De "avslutter" dem, "ofrer" dem eller "får dem fra hånden" (Luke1992). I Norge kaller pelsoppdretterne det "å pelse" når de avliver rev ved å stikke en strømførende stav inn i munnen og rektum på dem. Slik eufemistisk stempling er utbredt for å maskere forkastelige aktiviteter, eller for å få dem til å fremstå som respektable (Agnew 1997). På en lignende måte konstruerte torturistene i de chilenske og argentinske diktaturer et eget språk for grusom-hetene de utførte. Dette var også tilfellet i Holocausts byråkratiske termer (Cohen 2001).

Dyrene $e r$ forskjellige fra oss, men våre felles trekk kan være flere enn dem som skiller oss. For eksempel er smertereaksjonene de samme hos dyr og mennesker (Børresen 1996, Singer 1992). Også fisk kan føle smerte (Børresen 2000, Forsberg 2002). Et annet felles trekk er språk. Menneskespråket er beslektet med andre arters vokaliseringer, som de store apenes, syngende hvalers, padders og noen fuglearters (Børresen (1996). Det er registrert mer enn 300 ord i kråkespråket og Irene Pepperberg (1992) har gjennom studier av jacopapegøyen Alex vist at papegøyer kan skille abstrakte og konkrete begreper og har evne til å resonnere og skape nye ord, som når Alex kaller mais for steinkorn.

Men likhet kan ikke være et argument for å ikke plage og drepe andre, fordi konsekvensen ville bli at forskjeller legitimerer mishandling. 


\section{Kulturell legitimering som forklaring på bruk av dyr}

Religion og filosofi har hatt betydning for å gi en kulturell legitimitet til vårt syn på, og vår bruk av, dyr (Børresen 1996, Regan og Singer 1989, Cazaux 1999, Donovan 1990, Agnew 1998). Et annet eksempel fra filosofien er Aristoteles, som fastholdt at siden naturen ikke skapte noe uten en hensikt, måtte det følge at naturen hadde skapt både planter og dyr, for menneskets skyld.

Thomas Aquinas mente som Aristoteles at dyr har en sjel på en skala mellom planter og mennesker. Men siden dyr manglet fornuft, kunne ikke dyr være våre neste. Dyr kunne ikke ha noe fellesskap med mennesker, og derfor hadde mennesker ingen forpliktelser overfor dyrene. Aquinas erklærte derfor at dyr ikke har noen moralske rettigheter unntatt som menneskers eiendom. En måte å legitimere bruk av dyr på er dermed gjennom menneskers nytteverdi av det, slik filosofen Carl Cohen (2001) gjør i forhold til dyreforsøk i dag. Han hevder at det er absurd å tenke at dyr kan ha moralske rettigheter, fordi dyr ikke kan ha moral. Følgelig har mennesker rett til å bruke dyr.

Kristendommen legitimerer både avstand til og overgrep mot dyr, slik den fortolkes. I følge bibelen er både mennesker og dyr definert som deler av en helhet, som Guds skaperverk og eiendom. På den annen side er denne virkeligheten hierarkisk organisert, med mennesker på toppen med rett til å bruke de andre skapningene på jorden. Likevel er mennesker forpliktet til å beskytte de andre dyrene. Men siden mennesker har større verdi finner Østnor (1997) at hvis menneskers liv er i fare, må de gis prioritet.

At dyr må ivaretas gjenspeiles i mange religioner, fra jødedommen til kristendom, hinduisme, buddhisme og islam (Bowker 1986). Likevel viser rabbi David Bleich (1986: 68) til en rekke skriftsteder, og sier at innenfor jøde-dommen er kildene som forbyr ondskap mot dyr, ikke begrunnet $i$ hensynet til dyrene, men først og fremst $\mathrm{i}$ at onde handlinger mot dyr former karakteren slik at man spontant vil utøve onde handlinger. Motsatt former gode handlinger mot dyr mennesker slik at de utvikler medfølelse og barmhjertighet. Dyr skal derfor ikke først og fremst ivaretas for deres egen skyld, men for menneskenes.

Men dersom dyrene ikke har rettigheter i kraft av seg selv, men bare i kraft av hva de indirekte kan bety for mennesker, ved at de som objekter gir mennesket rom for å vise sin moral overfor dem, og derved overfor seg selv og andre mennesker, så vil dyrene få et svekket vern. Da blir dyr, på samme måte som om de brukes i matvareproduksjon, pelsproduksjon eller i eksperimenter, igjen objekter for menneskers handlinger, selv om disse handlingene skulle være gode. Likevel vil det å ikke respektere dyrs integritet også ha som konsekvens at menneskers verdighet reduseres, fordi måten man behandler andre på får betydning for egen selvforståelse. Hvis mennesket omdanner dyr til kun å være objekter for 
menneskers handlinger, vil mennesket stå ensomt og fattig tilbake (Børresen, 1996). Mennesket kan velge å utvide sin samhørighet til å omfatte omsorg og respekt for dyr og ved det utvide vår humanitet (Christoffersen 1991). Måter et samfunn behandler grupper uten makt på, enten det er flyktninger, minoritetsfolkeslag, fattige, eller dyr som de mest maktesløse, speiler samfunnets sivilisatoriske klima (Larsen 2002: 9).

Som religion og filosofi kan også jussen bidra til å legitimere menneskers behandling av de dyrene som brukes materielt. I den norske Dyrevernloven fremgår det at det er skjønnsmessig hvor grensen går for hva som er lidelse "i utrengsmål". At dyrs lidelse kan defineres som "nødvendig" lidelse, er i følge Cazaux et antroposentrisk standpunkt, som ivaretar menneskers interesser, ikke dyrs. Dyr mangler derfor legalrettslig beskyttelse. Dermed legitimeres det at dyr påføres smerte. Lovverket har i følge Beirne (1999: 129) vært en viktig strukturell og historisk mekanisme i konsolideringen av institusjonalisert dyremishandling.

Det er generelt godtatt i vårt samfunn at dyr som brukes av mennesker påføres lidelse og ubehag. Graden og typen av lidelsespåføring varierer mellom forskjellige land og er kulturbestemt (Frøslie 2000: 49).

Når menneskers rett til å benytte seg av dyr får en kulturell legitimitet, kan det øke vår mentale avstand til dyrene som sansende individer.

\subsection{Fysisk, mental og sosial avstand}

Denne avstanden skyldes også uvitenhet om dyrs lidelser, som kan skyldes at vi er fysisk avsondret fra dem. Slik er for eksempel slakteriene plassert langt fra der folk ferdes, for at få spor av den nærmest hemmelige slaktingen av dyrene på innsiden, skal nå menneskene på utsiden. Denne lokaliseringen var en konsekvens av de fremvoksende dyrevernbevegelsene i Europa på 1800-tallet (Vialle 1994). Og sannsynligvis øker utbredelsen av overgrepene mot dyr ved at de foregår i det skjulte. Det å stå fjernt fra husdyr og kjøttproduksjon kan bidra til at man fortrenger at det kjøttet man spiser har vært et levende dyr. En norsk undersøkelse viser at en av seks forbrukere mister lysten på kjøtt når de tenker på at kjøttet de spiser har vært et levende dyr (Berg 2002). Dersom vi rasjonelt sett ikke ser noen ting i veien for å spise kjøtt, burde vi kanskje avlegge slakteriet eller den industrielle gården et besøk, for å se om vi dermed ville føle annerledes. For når vi er fysisk fjernt fra konsekvensene av våre valg, når vi hverken kan se, lukte eller høre dem, fratar vi oss selv viktige sansestimuli som kunne rettlede våre etiske valg (Wheel 1996: 27, Agnew 1998).

Det er også legitimt at vi skjermer oss for konsekvensene av våre handlinger rettet mot dyr. Avstanden til dyrene som brukes, opprettholdes ved at det som foregår bevisst forties og skjules. For eksempel nektes dyrevernbevegelser å 
henge opp plakater som viser dyrs lidelser på offentlig steder, fordi det kan virke støtende på publikum (Adams 1996, Luke 1996).

Forsøkslaboratoriene er forskernes doméne og forsøkene kan bli unntatt offentlighet hvis det antas at forsøket vil vekke motstand hos publikum (Christoffersen 1997, Dyrevernrapport 1, 2002). Det er også et felt de fleste har lite kunnskap om, og hvor lidelsen dyr påføres er omfattende (Singer 1992, Regan 2001, m.fl.). Det at vi ikke ser dyrene i det industrielle husdyrholdet, i pelsdyrfarmen og forskningslaboratoriene, og det at de hopes opp, kan øke den sosiale avstanden (Shapiro 1996: 136). Det giør det vanskeligere å erkjenne dyrenes individuelle lidelse. Den kategoriske avstanden øker og gjør disse dyrene i enda større grad til "De andre", som står i et motsetningsforhold til oss selv.

Vi har dermed strukturert vårt samfunn slik, at det er mulig å ha et sterkt, følelsesmessig forhold til kjæledyr, samtidig som vi kan innta en pragmatisk og likegyldig holdning til dyrene innenfor industrielt husdyrhold. Det kan være vanskeligere å ta et standpunkt mot å spise dyr enn å spise dem, fordi det bryter med normer vi er sosialisert inn i. Et eksempel på sosialiseringsmekanismer som former oppfatninger om dyr er at kun $3 \%$ av alle "kosedyr" er kuer, griser eller kyllinger (Agnew 1998). Dyrene som brukes materielt gis i vårt samfunn nettopp ikke mulighet for å være del av vårt sosiale og moralske univers.

\section{Industrialisering, byråkratisering og fremmedgjøring}

Den teknologiske utviklingen har bidratt til en faktisk, fysisk avstand, som kan gjøre overgrep lettere. Zygmunt Bauman (1989) tar opp betydningen av dette $i$ forhold til overgrep mot mennesker, og viser at moral uunngåelig er forbundet med menneskelig noerhet. Ansvaret for den andre reduseres med avstanden. De moralske dimensjonene ved objektet viskes ut, til både ansvar og moral forsvinner ut av syne. Bauman understreker også teknologiens betydning for å produsere avstand og sier at faren for moralsk likegyldighet blir særlig akutt $\mathrm{i}$ vårt moderne, rasjonaliserte, teknologisk dyktige samfunn, for i et slikt samfunn kan menneskelig handling være effektiv på avstand, - en avstand som stadig øker med vitenskapelig, teknologisk og byråkratisk utvikling. Virkningen av menneskelig handling når langt utover det forsvinnende punktet for moralsk synlighet (Bauman 1989: 193).

Dyrene som brukes i det industrielle husdyrholdet og i eksperimenter tillates ikke å være sosiale dyr. Foring og rengjøring skjer automatisk, og elektriske "kutrenere" sikrer at kuene slipper avføringen i en renne. Vi opprettholder en sosial avstand ved å minimalisere kontakten med dyrene. De kan leve hele livet uten kontakt med mennesker, inntil de skal slaktes. Som mat, pels og forskningsobjekter får de et nummer. De er ikke unike individer vi har relasjoner til. Bau- 
man sier at i et nøtteskall beviste Milgrams kjente eksperiment, at umenneskelighet er et spørsmål om sosiale relasjoner. Etter som de blir rasjonalisert og teknisk perfeksjonert, øker evnen til, og effektiviteten av, den sosiale produksjon av umenneskelighet (Bauman 1989: 154).

Teknologiseringen av husdyrholdet kan forhindre at de som er ment å skulle se etter dyrene, faktisk ser dem. Bruken av teknologi fratar dyrene et sosialt liv, hvilket fører til psykoser som får dem til å oppføre seg unormalt. Når dette blir observert forsterkes inntrykket av at dyr er annerledes, og ikke "fortjener" å bli behandlet på noen annen måte. De blir "bare dyr" (Børresen 1996, 2000).

Kapitalisme og industrialisering innebar at mer økonomisk gevinst kunne utvinnes av dyrene. Ønsket om å maksimere profitt gir insentiver for mishandling, og profitten skaper sterke aktører som arbeider for fortsatt bruk av dyr (Agnew 1998). Et eksempel er at produksjon av dyr til bruk i forsøk er blitt en industri. Det annonseres for hårløse marsvin, og mus som allerede er påført kreft, i tillegg til alle variantene av tredemøllene som brukes for å påføre dyr elektriske støt, og apparater for fiksering av kaniner, hvis øyne skal dryppes med giftige substanser (Singer 1992). ${ }^{1}$

Industrialiseringen og den teknologiske utviklingen har ført til at mennesker fremmedgjøres i forhold til dyrene. Arbeideren på slakteriet jobber akkord. Jo flere han dreper, jo mer tjener han. Kyllingene henges opp levende etter føttene og automatisk kuttes hodene av. På et moderne slakteri kan 3000 kyllinger, 120 griser, 24 kyr eller 150-170 sauer og lam slaktes i timen (Klungsøyr 1991). Grisene drives frem til slakt ved hjelp av elektrosjokk, og det slurves ved bedøving, slik at grisen våkner opp der den er hengt opp etter bakbena og halspulsåren skal kuttes, eller i skåldekaret. En rapport fra et norsk slakteri viste at selv om grisene våknet opp, reagerte ikke slakteriarbeiderne før inspektøren ga dem beskjed om å bedøve grisene på nytt. ${ }^{2}$ I Vialles (1994) studie fra franske slakterhus fremgår det at én person har ansvaret for bedøvelsen, mens en annen har ansvaret for å kutte strupen på det opphengte, bedøvete dyret. Slik blir det vanskelig å fastslå akkurat når dyret dør, og dermed hvem som er direkte ansvarlig for det. Handlingen blir lettere å gjennomføre og slakteriarbeiderne blir fremmedgjort fra dyrene de dreper, og fra selve handlingen.

Et annet element av betydning for menneskets forhold til forbruksdyr, kan være det Milgram (1975) har kalt sequential action, altså gjentatte handlinger. Når en person har påtatt seg en jobb må han være trofast mot sine valg. Bauman (1989) kaller det den avgjørende innvirkning av et subjekts egne handlinger

\footnotetext{
${ }^{1}$ Se for eksempel www.colinst.com.

2 "Tilsynsrapport om driving og avlivning av gris", Næringsmiddeltilsynet Midt-Rogaland juli 1997, her fra NOAH 2002.
} 
(s.157). Det blir en felle. Hvis man tar avstand fra den siste handlingen må man ta avstand fra dem alle. Man kan ikke bli "ren" uten å sverte seg selv. På samme måte sier Singer (1992), at når en forsker har begynt med sine eksperimenter, er det vanskelig å bryte ut. Ikke bare er publisering og arbeid knyttet til dyreforsøkene, det samme er finansieringen. Han må derfor forbli fremmedgjort i forhold til sine forskningsobjekter. Et element ved dette kan knyttes til rutine, som én måte å benekte ansvar på. Med en gang man kommer over de første moralske hindere, soldaten dreper sin første sivile, torturisten bruker sitt første elektrosjokk - så blir det neste skrittet lettere. En grunn til å stoppe blir vanskeligere å finne, for det ville stille spørsmål ved det forrige skrittet (Cohen 2001: 90).

\section{Benektelse som forklaring på mishandling}

Cohen (2001) viser i sin bok States of Denial at mennesker til tross for at de vet at grusomheter finner sted, på forskjellige måter benekter at det foregår. De blokkerer ut sannheten og nyhetene. Cohen kaller benektelse; "the need to be innocent of troubling recognition" (2001: 39). Theodore Barber, en atferdsforsker, kan illustrere det. Han hevdet i 30 år, at fugler bare var instinktbunter. Så bestemte han seg for å lese all tilgjengelig litteratur om dyrs, og særlig fuglers, intelligens. I seks år studerte han. Han sier:

"Siden jeg tidligere hadde akseptert det offisielle vitenskapelige synet at fugler er instinktstyrte automater, ble jeg skrekkslagen da det gikk opp for meg at det offisielle tabuet mot antropomorfisme hadde blokkert meg og praktisk talt alle andre forskere fra å oppdage virkeligheten, og dermed våre narmeste naboers, fuglenes, intelligente natur. Forskningsresultatene viste klart det som den offisielle vitenskapen standhaftig benektet: Fugler har bevissthet og følelser. De har tydelig forskjellige personligheter, og de vet hva de holder på med" (Børresen 1996: 160).

Benektelser er avhengige av felles kulturelle vokabularer for å være troverdige (Cohen 2001). Benektelsen deles på en mektig måte gjennom menneskers involvering i hverandre. Evnen til å begå onde handlinger vil øke hvis flere personer utøver dem sammen, for samarbeid vil alltid være knyttet til grensetrekking og ekskludering av andre. Dette vil øke gapet mellom subjektene og objektene for handling og gjøre forvandlingen fra aktør til forfølger, og fra objekt til offer lettere (Bauman 1989: 157).

Benektelsen opprettholdes ved å rette oppmerksomheten vekk fra de ubehagelige fakta, gjennom nøytraliseringsteknikker som for eksempel minimalisering. Slik kan vi redusere dyrene til kjøtt, pels eller forskningsobjekter. Kenneth Shapiro (1992: 135) diskuterer hva som gjør at noen mennesker blir dyrerettighetsaktivister, mens andre forblir uberørt. Der noen kun ser en pelskåpe, ser 
andre døde dyr, utnyttelse og lidelse. Dette knytter han til en utilsiktet ansvarsfraskrivelse hos dem som ikke ser lidelsen, som spurt direkte kan vedkjenne seg at de er klar over problemet, men de er i stand til å blokkere en full emosjonell bevissthet om det ute. Likeledes viser Bergs undersøkelse (2002) om nordmenns forhold til dyrevelferd, at kvinner i mindre grad enn menn ønsker informasjon om dyrevelferd. Samtidig er de mer bekymret for hvordan dyr har det. Dette tolkes som at de ønsker å beskytte seg mot egen følsomhet, og at det er en ønsket fortrengning. Selv om de fleste aner hva som foregår, er det mest behagelig å ikke vite. Refleksjon rundt dyrenes velferd er fraværende for de fleste, når de gjør sine innkjøp. Amerikanske undersøkelser viser tilsvarende at mennesker aktivt tar del i aktiviteter som medfører dyremishandling, samtidig som de er opptatt av dyrevelferd (Agnew 1998). Shapiro trekker en parallell til det å være vagt bevisst om, men å benekte de fulle implikasjoner av dyrs lidelse, og det å vite om, men likevel ikke være emosjonelt bevisst en fjern sultkatastrofe, slik Cohen (2001) også viser til. En annen måte å benekte sin egen rolle i dyremishandling, kan være ved å si at det er så mange som tar del i det, at eget bidrag likevel blir så lite og dermed har få konsekvenser.

Slik er det mulig å lukke ute det dyr utsettes for. Det kan også ses i lys av det Cohen (2001) kaller "fortolkende benektelse". Som forskere, bønder, slakteriarbeidere og konsumenter benekter vi ikke hva som faktisk finner sted, men karakteren av det. Dyrene føler ikke smerte, eller smerten er ikke viktig for oss. En slik benektelse kan defineres som en av Sykes' og Matzas (1957) nøytraliseringsteknikker; nemlig benektelsen av offeret.

Benektelsen kan også skyldes det Hannah Arendt kaller ondskapens banalitet, som ikke er en minimalisering av ondskap, men heller innebærer at ufattbar ondskap kan være et resultat av ordincere, menneskelige egenskaper. Det at man ikke innser hva man gjør, men gjør det som et resultat av helt normale faktorer, som jobbambisjoner, trygghet og noe man gjør sammen med andre (Cohen 2001: 101).

Det er mulig å kalle dette en form for kulturell benektelse. Kulturell benektelse innbærer en kollektiv blindhet, som lar grusomhet pågå som en normalisert del av menneskers livsrytme. Når Cohen (2001) bruker begrepet, refererer han til overgrep mot mennesker. Men kanskje kan vi også si at det grisen, forsøksdyret, minken og burhønen opplever i vårt moderne, vestlige samfunn er konsekvens av kulturelle benektelser, for behandlingen særlig dyr i fangenskap utsettes for defineres ikke som mishandling. I den grad vi har behov for det får vi dermed hjelp til å benekte hva som foregår. Slik kan mishandling bli sosialt akseptert. Den sosialt aksepterte mishandlingen involverer oftest indirekte skade og er nesten alltid betraktet som nødvendig, eller for å tjene et tvingende menneskelig 
behov (Agnew 1998). De som har størst nytte av mishandlingen vil være mest tilbøyelige til å utvikle moralske rettferdiggjøringer og ta minst avstand fra den.

Dyremishandling vekker sterke reaksjoner hvis en hundevalp er offeret, men det at høns stenges inne i trange bur og manipuleres til å legge store egg hver dag forsvares ut fra økonomiske interesser (Christie 1989).

I vårt forhold til dyr må vi derfor innta en fenomenologisk tilnærming, hvor vi må forsøke å sette oss i inn i dyrets situasjon og slik muliggjøre empati. Max Scheler løfter sympati til å bli en epistemologisk form for forståelse, når han sier at forskeren må bruke sin fantasi for å sette seg inn i et individs virkelighet, det være seg menneske eller dyr (Donovan 1996). Sympati er grunnlaget for medfølelse, og grenseløs medfølelse med alle levende skapninger er den sikreste garanti for ren moralsk atferd (Schopenhauer i Donovan 1996: 155). Følgen av å sympatisere med andre sansende vesener er at vi ser dem som subjekter med egenverdi og egne rettigheter. Dermed kan vi ikke bruke dem etter våre egne behov.

Målet kan formuleres som Singer gjør det, når han sier at:

"Smerte og lidelse er onder som bør forhindres eller minimaliseres, uavhengig av en skapnings rase, kjønn eller art" (Singer 1979: 8).

\section{Referanser:}

Agnew, Robert (1998): "The causes of animal abuse: A social-pshycological analysis" I Theoretical Criminology Vol. 2 (2): 177-209.

Adams, Carol (1996): "Caring about suffering: A feminist exploration" I Donovan, J og Adams, C.J. (red.): Beyond animal rights. New York, s. 170-196.

Bauman, Zygmunt (1989): Modernity and the Holocaust. Polity Press.

Beirne, Piers (1995): "The use and abuse of animals in criminology" I Social Justice $n$ r. 1, s.5-31.

Beirne, Piers (1999): "For a nonspecisist criminology. Animal abuse as an object of study". I Criminology. An interdisciplinary journal. The official publication of the American Society of Criminology. Number 1, february 1999, s.117-149.

Berg, Lisbet (2003): Dyrevelferd i Norge 2002. Oppdragsrapport nr. 10- 2002. Statens institutt for forbruksforskning.

Bowker, John (1986): "Introduction: Religions and the Rights of Animals" I Rea gan, Tom (red.) Animal Sacrifices. Religious Perspectives on the Use of Animals in Science.

Børresen, Bergljot (1996): Den ensomme apen. Instinkt på avveie. Gyldendal, norsk forlag. Oslo. 
Børresen, Bergljot (2000): "Menneskets medfødte forutsetninger som vertskap for produksjonsdyr" I Føllesdal, Andreas (red.): Dyreetikk. Fagbokutvalget.

Cazaux, Geertrui (1999): "Beauty and the Beast: Animal abuse from a nonspeciesist criminological perspective" I Crime, Law and Social Change.

Vol. $31 \mathrm{nr}$. 2, s. 105-126.

Cazaux, Geertrui (1999): "Legitimating the entry of 'The animals issue' into (critical) criminology". I Humanity and Society. Volume 22, Number 4,November 1998, s. 365-385.

Christe, Nils (1989): "The utility of violence. I Panopticon, s.20-26.

Christoffersen, Svein Aage (1991): "Forsøk med dyr- prøve på humanitet" I Kirke og kultur 3/1991, s. 227-241.

Christoffersen, Svein Aage (1997): "Forsøk med dyr- er det etisk forsvarlig?" I Tidsskrf. Norsk laegeforening $n r, 8,1997$ : 1068-9.

Christoffersen, Svein Aage (2000): "Hvordan bør dyr telle? Synspunkter fra et kristent perspektiv." I Føllesdal, Andreas(red.): Dyreetikk. Fagbokutvalget.

Cohen, Stanley (2001): States of denial. Polity Press.

Cohen, Carl and Regan, Tom (2001): The Animal Rights Debate. Rowman and Littlefield Publishers, inc.

Donovan, Josephine (1990): "Animal Rights and Feminist Theory" I Signs. Journal of women in culture and society. Vol. 15: 2, s.350-376.

Donovan, Josephine (1996): "Sympathy as a Basis for Ethical Treatment of Animals" I Donovan J, og Adams, C.J. (red.): Beyond animal rights. New York, s. 147-170.

Dyrevernrapport: Forsøksdyr- levende dyr brukt som måleinstrumenter. Dyrevernalliansen. Rapport nr. 1, 2002.

Forsberg, Ellen-Marie (2002): "Verdidebatt om fisk og smerte i Tromsø." I Forskningsetikk. Nr. 3-02, s.10-11.

Frøslie, Arne (2000): "At dyr ikke skal lide i 'utrengsmål'” I Føllesdal, Andreas (red.): Dyreetikk. Fagbokutvalget.

Føllesdal, Andreas (2000): "Meninger med målløst liv. Noen hovedretninger innen dyreetikk." I Føllesdal, Andreas (red.): Dyreetikk. Fagbokutvalget.

Gendin, Sidney (1986) i Animal sacrifices: religious perspectives on the use of animals in science (red. Tom Regan) Philadelphia Temple University Press. Kheel, Marti (1996): "The Liberation of Nature: A Circular Affaire" I Donovan J, og Adams, C.J. (red.): Beyond animal rights. The Continuum Publishing Company. New York, s. 17-34.

Klungsøyr, Liv (1991). Vi kaller det utvikling: når husdyrhold blir industri. Norsk liga for dyrs rettigheter. 
Larsen, Guri (2002): Samfunnets dyrevern- dyras vern mot lidelse? Om anmeldt dyremishandling $i$ Oslo-området. Rapport, institutt for kriminologi og rettssosiologi.

Luke, Brian (1996): "Justice, Caring and Animal Liberation" I Donovan J, og Adams, C.J. (red.): Beyond animal rights. New York, s. 77-103.

Milgram, Stanley (1975): Obedience to authority. Harper torchbooks. Harper \& Row, Publishers.

Pepperberg, Irene (1992): "Proficient Performance of a Conjunctive, Recursive Task by an African, Grey Parrot" I Journal of Comparative Psychology, 1992, 106 no.3, s. 295-305.

Regan, Tom (1999): Djurens rettigheter, en filosofisk argumentation. Förlaget Nye Doxa.

Regan, Tom og Singer, Peter (1989): Animal Rights and Human Obligations. Prentice Hall inc.

Shapiro, Kenneth (1996): "The Caring Sleuth: Portrait of an Animal Rights Activist" I Donovan J, og Adams, C.J. (red.): Beyond animal rights. New York, s. 126-147.

Singer, Peter (1992): Djurens frigörelse. Nye Doxa.

Sykes, Gresham and David Matza (1957): "Techniques of neutralization" I American Sociological Review 22, 664-70.

Vialle, Noëlie (1994): From animal to edible. Cambridge university press. Paris. Østnor, Lars (1997): "Respekt for dyrenes liv". I Samtiden 5/6 1997: 40-46.

Adresse:

Norsk Institutt for forskning om oppvekst, velferd og aldring (NOVA)

Postboks 3223, Elisenberg

N- 0208 Oslo

Ragnhild.Sollund@nova.no 